\title{
Relasi Media Destinasi Superprioritas Mandalika dalam Pemberitaan Kesiapan Pelaksanaan Event MotoGP 2021
}

\author{
Siti Chotijah \\ Universitas Mataram, Indonesia \\ Contact: mbakjhe@gmail.com
}

\begin{abstract}
Mandalika as super-priority destination is one of the main focuses of national tourism destination in Indonesia. Especially with the MotoGP event planned in October 2021, Mandalika MotoGP is the famous of Indonesian tourism event. Covid-19 pandemic during 2020 caused pessimism related to the grand event which take place in October 2021, also the dorna release about mandalika in MotoGP 2021 schedule mentioned as reserve date. Reserve date of mandalika misleading and built negative perception and the puclic trust was droped into pessimism. Seeing this problem is necessary to conduct communication strategy and media relation strategy by the ITDC and also related parties to persuade public by the media. This research is a qualitative descriptive study that explains media relation strategies Mandalika as a super-priority destination in welcoming the MotoGP 2021 event. From this discussion Mandalika as superpriority destination runs various communication program by using various kind of media through publication, exposure and making approach through framing and agenda setting on information distribution. Apart from this, ITDC and various parties also lobbies as well as negotiated and continue to communicate positive message for creating optimism about the Madalika MotoGP event.
\end{abstract}

Keywords: Media Relation, Mandalika, Superpriority Destination, MotoGP 2021

\begin{abstract}
ABSTRAK
Mandalika sebagai destinasi pariwisata superprioritas menjadi salah satu fokus utama pariwisata nasional. Terlebih dengan adanya even MotoGP yang direncanakan akan digelar pada oktober 2021 menjadikan Mandalika sebagai salah satu primadona utama pariwisata Indonesia. Perencanaan yang awalnya berjalan baik terhambat dengan adanya pandemi covid-19 sehingga menimbulkan pesimisme publik terkait dengan even akbar yang akan berlangsung oktober mendatang. Banyak pemberitaan yang menyudutkan Mandalika terkait kesiapan perhelatan MotoGP. Melihat permasalahan ini perlu dilakukan komunikasi strategis guna mengkomunikasikan kesiapan sekaligus meyakinkan publik tentang kesiapan pemerintah dalam hal ini ITDC dan juga pihak terkait untuk pelaksanaan even MotoGP Mandalika di 2021. Penelitian ini merupakan penelitian diskriptif kualitatif yang menjelaskan tentang relasi media Mandalika sebagai destinasi superprioritas dalam menyambut even MotoGP 2021. Dari hasil pembahasan, Mandalika sebagai destinasi superprioritas menjalankan berbagai program komunikasi dengan memanfaatkan berabgai macam media melalui exposure dan melakukan pendekatan melalui framing dan agenda setting pada distribusi informasi. Selain hal tersebut ITDC dan juga berbagai pihak melakukan lobby sekaligus negosiasi dan terus mengkomunikasikan pesan positif kepada masyarakat secara strategis dan terencana dengan tujuan menciptakan optimisme tentang perhelatan MotoGP Mandalika.
\end{abstract}

Kata Kunci : Relasi Media, Mandalika, Destinasi Superprioritas, Moto GP 2021

\section{Pendahuluan}

Presiden Joko Widodo telah menetapkan 5 destinasi pariwisata superprioritas pada rapat terbatas kabinet yang dilaksanakan di Jakarta pada 15 Juli 2019 (Kemenkomarves, 2020). Kelima destinasi pariwisata superprioritas itu adalah Labuan Bajo ( NTT), Mandalika ( NTB), Borobudur (Jawa Tengah), Danau Toba (Sumatera Utara) dan Likupang (Sulawesi Utara). Penetapan ini menjadi perhatian publik dikarenakan berbagai pembangunan infrastruktur yang 
dapat disebut sebagai mega proyek serta branding superprioritas yang melekat menjadi daya tarik bukan hanya bagi pengamat pariwisata namun juga masyarakat Indonesia.

Mandalika sebagai salah satu dari lima destinasi superprioritas memiliki daya tarik tersendiri. Selain bentang alam yang indah, KSPN yang memiliki luas 1.024 hektar ini akan menjadi fokus dunia dengan adanya even MotoGP. Even sport tourism bertaraf internasional ini direncanakan akan digelar pada Oktober 2021. Hal ini tentu menjadi perhatian banyak pihak, sekaligus menjadi harapan bagi Nusa Tenggara Barat serta Indonesia dalam mewujudkan angka kunjungan wisatawan baik domestik maupun mancanegara. Rencana perhelatan MotoGP Mandalika ini telah menjadi perbincangan dari tahun 2018. Indonesia Tourism Development Center ( ITDC) The Mandalika sebagai badan usaha milik negara yang mengelola kawasan Mandalika telah melakukan promosi sekaligus persiapan sedemikianrupa.

Pandemi Covid yang saat ini terjadi dan berawal dari Desember 2019 telah mengubah kondisi dunia termasuk sektor pariwisata. Melalui berbagai kebijakan penanganan pandemi, pariwisata menjadi salah satu sektor terdampak dikarenakan pembatasan mobilitas manusia. Hal ini tentu memberikan pukulan yang signifikan terhadap berbagai perencanaan yang dilakukan dalam pariwisata Indonesia termasuk perhelatan MotoGP Mandalika. Pembangunan sempat dihentikan beberapa saat, seiring dengan pembatasan kegiatan masyarakat di setiap sektor. Kebijakan ini sedikit memperlambat pembangunan sirkuit MotoGP Mandalika dan memunculkan rasa pesimistis publik teradap perhelatan ini.

Pada November 2020 berbagai media ramai-ramai memberitakan tentang posisi Mandalika dalam perhelatan MotoGP musim 2021 dimana Mandalika termasuk dalam reserve date ( Kompas, 2020). Pemberitaan ini mengejutkan publik, dikarenakan ekspektasi publik yang selama ini berkeyakinan bahwa Mandalika akan masuk menjadi salah satu race MotoGP pada musim 2021. Pemahaman masyarakat tentang reserve date ini kebanyakan berpendapat bahwa Mandalika belum pasti menjadi race MotoGP 2021. Sehingga muncul rasa pesimis dan kecewa dari masyarakat dan menjadi berita yang trending di berbagai media. Kondisi ini menjadi perbincangan hangat sehingga menjadikan Mandalika dalam hal ini ITDC dan lembaga terkait seperti Pemprov NTB, Kementerian Pariwisata dan Ekonomi Kreatif (Kemenparekraf), Kemenkomarves, KemenPUPR dan lainnya harus melakukan klarifikasi dan melakukan tindakan komunikasi sebagai upaya menjawab kekhawatiran publik dan memunculkan rasa optimisme bersama tentang pergelaran MotoGP Mandalika. Penelitian ini melihat pada bagaimana relasi media yang dilakukan Mandalika sebagai destinasi superprioritas dalam menyambut even MotoGP 2021 dan berfokus pada bagaimana relasi media yang dilakukan khususnya dalam menjelaskan permasalaha reserve date yang sempat menimbulkan pesimisme masyarakat.

\section{Strategi Komunikasi}

Strategi komunikasi dipahami sebagai gabungan antara perencanaan dan manajemen. Perencanaan yang dimaksud merupakan perencanaan komunikasi melalui kombinasi berbagai tahap seperti melakukan analisis situasi, analisis audiens, penyusunan pesan serta pemilihan media. Manajemen komunikasi dipahami sebagai pengaturan pelaksanaan komunikasi yang melibatkan komunikator, komunikan, pesan, media dan feedback. Strategi komunikasi 
merupakan perencanaan efektif dalam menyapaikan pesan oleh komunikator kepada komunikan dengan tujuan tertentu dengan menggunakan media ( Effendy, 2011).

Beberapa teknik dalam strategi komunikasi diantaranya adalah repetisi atau redudansi, informatif, persuasif, kanalising, edukatif dan koersif (Arifin, 1994). Repetisi yaitu cara mempengaruhi khalayak secara berulang sehingga pesan akan mudah diingat. Informatif bermaksud menyebarluaskan informasi. Persuasif berarti mempengaruhi khalayak melalui pesan. Edukasi merupakan pesan komunikasi yang berisi pendapat, fakta dan pengalaman yang diberikan oleh komunikator. Sedangkan koersif merupakan teknik mempengaruhi dengan sedikit memaksa. Kanalising merupakan upaya mempengaruhi masyarakat dengan standar tertentu agar mudah diterima.

\section{Media Relations}

Media relation adalah aktivitas suatu perusahaan atau lembaga untuk menjalin hubungan baik dengan media, kalangan pers dan wartawan. Media relation merupakan bagian tugas dari seorang humas. Media relation dilakukan untuk mendapatkan pemberitaan, publisitas maupun liputan media sebanyak mungkin. Humas dalam melakukan media relations berbanding lurus dengan citra perusahaan dan meningkatkan kepercayaan khalayak sehingga dapat menunjang popularitas dari suatu lembaga atau produk (Kasali, 2000).

Media relations memiliki fungsi di antaranya adalah untuk meningkatkan citra perusahaan, meningkatkatkan kepercayaan dan poin interes publik, membantu penanganan krisis dan meningkatkan relasi dengan pihak lain. Media relation memiliki berbagai jenis aktivitas di antaranya adalah konferensi pers, press briefing, media visit, undangan liputan, press gathering dan press tour (Jefkins, 2000). Media relations adalah upaya sistematis untuk menggunakan platform media dalam membentuk opini publik. Melalui penggunaan media dapat meningkatkan publisitas dan menyebarluaskan informasi. Media relation dapat dijadikan kegiatan penunjang untuk meningkatkan loyalitas publik dan mempererat hubungan baik.

\section{Strategi Media}

Strategi media adalah suatu rangkaian kegiatan untuk memilih media yang akan digunakan dalam proses komunikasi. Media strategi dapat disebut sebagai media planning yaitu membuat suatu desain komunikasi agar efektif efisien dan menjangkau khalayak sesuai target (Shimp, 2010). Humas dalam melakukan media strategi sering melakukan media mix yaitu menggabungkan berbagai jenis media dalam suatu program komunikasi untuk mendapatkan terpaan media yang maksimal. Media mix atau bauran media ini merupakan penggabungan jenis media baik media cetak, media digital maupun media yang lain.

Pada konsep produk pariwisata atau even pariwisata kita mengenal ada empat macam jenis media yaitu paid media ( media berbayar), own media ( media internal) sosial media dan endorser. Paid media adalah segala jenis media yang jika menggunakan maka kita wajib membayar seperti televisi, media online komersial maupun media luar ruang. Media internal adalah media yang dimiliki oleh suatu perusahaan atau organisasi dan dapat digunakan untuk memaksimalkan penyebaran informasi seperti website, buletin dan media yang dimiliki. Sosial 
media adalah media baru yang bersifat lebih personal. Suatu perusahaan atau organisasi biasanya memiliki sosial media resmi sebagai bentuk penggunaan sosial media. Endorser merupakan penggunaan jasa orang atau lembaga yang diyakini mampu mempengaruhi khalayak.

\section{Metode}

Penelitian ini merupakan penelitian diskriptif kualitatif dan berfokus pada bagaimana relasi media Mandalika sebagai destinasi superprioritas dalam melakukan distribusi informasi kesiapan penyelenggaraan even MotoGP 2021. Penelitian kualitatif diskriptif menghasilkan data berupa kata- kata dari bebagai bentuk tindakan yang menjelaskan fenomena yang diamati (Moeleong, 2002). Metode pengumpulan data pada penelitian ini menggabungkan antara observasi, wawancara dan studi dokumen. Observasi dilakukan peneliti baik secara langsung maupun tidak langsung melalui pengamatan pada berbagai kegiatan yang dilakukan oleh ITDC, Kementerian terkait dan Pemerintah daerah. Wawancara dilakukan kepada pihak yang terlibat yang mewakili berbagai elemen seperti pemerintah provinsi NTB, pengamat pariwisata dan komunitas partner. Studi dokumen dilakukan selama periode November 2020 hingga Januari 2021 dengan melihat publikasi pada media, bahan presentasi maupun materi diskusi dari para pemangku kebijakan. Validitas data pada penelitian ini menggunakan triangulasi sumber yaitu data wawancara, observasi dan studi dokumen.

\section{Hasil dan Pembahasan}

Strategi komunikasi termasuk strategi menjain relasi dengan media menjadi penting dilakukan untuk mendapatkan dukungan masyarakat. Komunikasi selalu berkaitan dengan pesan, komunikator, komunikan, media dan efek. Formulasi ini menjadi elemen yang sama sama penting. Dalam membuat strategi harus mampu mengenal khalayak, menyusun pesan komunikasi, menetapkan metode serta menggunakan media ( Arifin, 2004 dalam Mahrik 2016). Berbagai langkah strategis dilaksanakan untuk mendukung pembangunan mandalika sebagai destinasi super prioritas (DSP). Selain berfokus pada percepatan pembangunan infrastruktur dan SDM salah satu fokus yang dilaksanakan oleh berbagai pihak adalah pemasaran dan promosi. Selain ITDC The Mandalika sebagai operator Mandalika berbagai kementerian turun tangan dalam mewujudkan Mandalika sebagai salah satu DSP utama yang pada tahun 2021 ini direncanakan akan menggelar even akbar dan perdana MotoGP Mandalika.

Mandalika setelah ditetapkan sebagai DSP pada 2019 lalu memang memerlukan komunikasi bukan hanya mensosialisasikan kebijakan namun juga membentuk persepsi dan branding Mandalika sebagai destinasi utama dengan even internasional MotoGP. Dalam penelitian yang dilakukan ditemukan sinergi yang terencana antar berbagai elemen pemerintah untuk bersama memasarkan dan mempromosikan Mandalika termasuk dalam menjalin hubungan atau relasi dengan berbagai media.

Setelah mispersepsi publik dengan status reserve date yang terjadi pada November 2020 lalu berbagai elemen bersinergi dan sigap dalam menetralisir pemberitaan dan perbincangan Mandalika. Berbagai upaya dilakukan oleh berbagai elemen dengan meningkatkan program komunikasi dan pemasaran Mandalika. Salah satu hal utama yang 
dilakukan adalah dengan melakukan distribusi informasi melalui berbagai media baik media online (digital), media cetak dan media elektronik (Faozal, 2020) .

Pesan yang disampaikan bukan hanya oleh ITDC sebagai operator Mandalika, Kementerian terkait dan Pemerintah Daerah Provinsi NTB dan Kabupaten Lombok Tengah semua melakukan hal yang sama yaitu berisi tentang tema kesiapan dan optimisme Mandalika dan perhelatan MotoGP Mandalika 2021. Berbagai pihak melakukan konferensi pers, mengeluarkan rilis media resmi maupun melakukan blocking space media untuk pemberitaan Mandalika. Berbagai judul berita yang ditayangkan oleh berbagai media pada kurun waktu desember 2020 hingga januari 2021 diantaranya adalah berisi tentang dukungan pemerintah dalam penyelesaian infrastruktur ( Kemenkomarves, 2020), keberhasilan pre-sale tiket MotoGP Mandalika, Progres pembangunan sirkuit, Kesiapan Mandalika dalam menggelar even MotoGP, Pernyataan dari key opinion leader tentang optimisme Mandalika dan bantahan bahwa posisi Mandalika dalam Even MotoGP bukan cadangan (Kompas, 2020). Bahkan Presiden Jokowi menyataan bahwa Indonesia siap menggelar even MoGP ( Liputan6, 2020).

Pemberitaan dimedia menjadi langkah utama dalam meluruskan pemahaman reserve date. Melalui penjelasan diberbagai media reserve date bukan berarti sebagai cadangan namun Dorna selaku pihak penyelenggara MotoGP memberikan kebebasan bagi Indonesia ( Mandalika) untuk menentukan tanggal pelaksanaan event MotoGP. Pemberitaan ini diharapkan menjadi klarifikasi serta upaya untuk memberikan informasi update dan meluruskan pemahaman publik yang tidak tepat. Dalam wawancara yang dilakukan peneliti terhadap pengamat pariwisata NTB Taufan Rahmadi mengatakan bahwa pemberitaan menjadi penting untuk meluruskan persepsi public dan diperlukan media untuk menetralisir isu (Taufan, 2020).

ITDC dan juga pihak terkait (Kementerian dan Pemerintah daerah) dalam hal ini dapat kita analisis menggunakan agenda-setting theory dimana pihak terkait yang mengatasnamakan mandalika menggunakan media untuk mempengaruhi persepsi publik melalui pemberitaan dimedia. Melalui pemberitaan dimedia, pihak pihak terkait ini bertujuan untuk meningkatkan kesadaran, memberikan informasi dan menekankan hal hal yang dianggap penting untuk dapat diterima oleh pembaca (masyarakat) sebagai sebuah informasi valid dan dapat dipercaya (McCombs dan Shaw dalam Griffin, 2010). Hal ini dilakukan secara terencana dan sistematik sehingga menimbulkan satu keserempakan gerakan dan dari berbagai sudut. Berawal dari fenomena sikap pesimis dari masyarakat tentang even MotoGP Mandalika 2021 diubah persepsi melalui pemberitaan media dan selanjutnya persepsi dapat dirubah dengan berbagai pemberitaan yang massif.

Pemberitaan dilakukan tidak hanya sekali dan tidak hanya pada satu media. Pemberitaan dilakukan berkali kali dengan melibatkan sebanyak mungkin media dengan konten dan framing berita yang hampir sama. Selain itu, pihak ITDC dan berbagai kementerian juga terus mengeluarkan informasi positif dan menjadikannya sebagai informasi pendukung untuk meningkatkan optimisme masyaakat tentang kesiapan Mandalika dalam MotoGP 2021.

Media yang digunakan dalam menyampaikan informasi terkini dan tema tema besar pada paragraph sebelumnya merupakan media yang valid dalam hal ini adalah media official 
dari berbagai lembaga negara seperti website official dari Sekretariat Kabinet, Kemenkomarves, ITDC, KemenPUR, Kemenparekfaf mapun Kominfo. Seperti yang kita ketahui salah satu domain terpercaya di Indonesia adalah domain go.id dimana informasi didalamnya adalah official bersumber dari pemerintah yang dapat dipertanggungjawabkan dan berbiacara atas nama negara. Bukan hanya media berbasis website, namun informasi atau agenda seting informasi juga disampaikan melalui media sosial official dari berbagai pihak. Bahkan pada masa penelitian peneliti melihat keseragaman informasi ini dilakukan dalam waktu yang bersamaan dan berulangkali.

Berbagai pemberitaan pada media nonpemerintah pada periode November 2020 hingga januari 2021 tentang Mandalika juga mendominasi untuk kategori berita pariwisata dan destinasi. Media yang digunakan untuk mendistribusikan informasi juga sangat beragam baik media nasional, internasional maupun lokal. Seperti contoh adalah halaman Kompas travel, detik sport, Kompas TV, Koran Tempo, Media jaringan JPNN, Indosport, Liputan6.com, Otomotif Kompas dan berbagai chanel TV nasional. Pemerintah lokal juga melakukan publikasi media pada media lokal seperti Radar Mandalika, Lombok Post, Kicknews, Suara NTB dan media lokal lainnya baik cetak, online maupun elektronik.

Berbagai Kementerian terkait bahkan bukan hanya menyajikan informasi dalam bentuk pemberitaan media, namun juga melakukan produksi konten yang ditayangkan melalui media internal dari tiap pihak. Konten tersebut merupakan konten video, foto maupun infografis terkait Mandalika dan kesiapan menuju even MotoGP 2021. Berbagai konten ini di-publish dalam setiap media baik itu own media, paid media, media sosial dan dilakukan endorsement pada key opinion leader. Paid dan own media melibatkan bauran berbagai media advertising yang digunakan untuk mendorong pemasaran seperti billboard dan advertorial diberbgai jenis media.

Sebagai strategi komunikasi dan pemasaran Mandalika khususnya dalam membentuk optimisme publik, investor maupun calon wisatawan yang menajdi target market dari perhelatan MotoGP informasi selalu diberikan oleh spoken person yang memiliki kredibilitas dan terpercaya seperti Presiden Joko Widodo, Menteri terkait, Direktur Utama ITDC, Gubernur NTB, Kadipas NTB maupun Dorna selaku pihak penyelenggara MotoGP. Strategi ini dinilai baik dan kuat dalam mendapatkan atensi publik, menjamin bahwa informasi official dan dapat dipercaya sekaligus memberikan dampak psikologis kuat yaitu rasa percaya pada pembaca.

Sebagai penguatan pesan komunikasi tentang kesiapan Mandalika dalam menggelar MotoGP, selain menggunakan media sebagai sarana penyebarluasan pesan, forum offline melalui komunikasi dan koordinasi dilakukan oleh berbagai pihak. Seperti contoh adalah kegiatan bimbingan teknis yang melibatkan berbagai stakeholder baik dari pemerintah, industri, akademisi, komunitas dan bisnis. Forum ini memiliki fungsi utama yaitu sebagai sarana sosialisasi perkembangan dan langkah strategis khususnya dalam pemasaran dan promosi. Pada bulan Desember 2020- Januari tercatat setidaknya 5 kegiatan Bimtek dan sosialisasi DSP dan kesiapan Mandalika. Berbagai penyelenggaraan kegiatan diberitakan melalui media lengkap dengan kutipan dari pemangku kebijakan tentang kegiatan dan kesiapan Mandalika 
dalam menggelar even MotoGP. Pada setiap kegiatan media dilibatkan sebagai jembatan informasi Mandalika dengan masyarakat.

Mandalika dan even MotoGP menjadi perbincangan dan kerap menjadi pembahasan dalam berbagai forum termasuk webinar. Melalui webinar ini, para narasumber termasuk dari pemangku kebijakan menjadikan forum ini sebagai forum sosialisasi sekaligus menghimpun dukungan untuk Mandalika dan even MotoGP. Webinar dilaksanakan oleh pemerintah melalui berbagai kementerian maupun lembaga lembaga pendidikan dan komunitas dan menjadikannya sebagai ruang publik dimana pertukaran informasi sangat dimungkinkan terjadi. Kegiatan webinar juga disertai dengan kegiatan publikasi baik dari pihak Mandalika maupun penyelenggara.

Pranata humas dari berbagai institusi yang memiliki tupoksi promosi dan pemasaran mandalika dalam observasi yang dilakukan juga melakukan media relations secara berkesinambungan. Membangun relasi dengan media menjadi sangat penting untuk distribusi informasi, melakukan konferensi pers, press release maupun door stop jika ada pejabat atau key opinion leader yang hadir melakukan kunjungan kerja dikawasan Mandalika. Seperti dicontohkan kunjungan kerja Menparekraf Sandiaga Uno pada pertengahan januari lalu dilengkapi dengan berbagai undangan kepada media untuk menyertai semua kegiatan pada agenda kunjungan kerja.

Strategi komunikasi pemasaran Mandalika dalam kesiapan menyambut MotoGP didukung oleh partisipasi publik pada lingkar DSP. Pada observasi yang dilakukan khususnya pada media sosial ada gerakan dari masyarakat lingkar DSP khususnya para penggiat pariwisata yang turut mempromosikan dan mendukung perhelatan MotoGP. Seperti dicontohkan adalah hastag \#Roadto2021 yang digunakan para pegiat desa wisata dan masyarakat sekitar Mandalika. Kontribusi masyaraat baik lokal maupun pengunjung mandalika dapat dilihat pada kontribusinya pada media sosial pribadi. Partisipasi dilakukan dengan membagi konten disertai dengan caption yang mendukung perhelatan MotoGP.

Melihat bahwa masyarakat Indonesia aktif dalam menggunakan media sosial, relasi media bukan saja dilakukan dengan media konvensional namun juga merambah pada relasi media melalui platform sosial media. Berbagai kegiatan dilakukan dengan menjalin hubungan baik dengan para influencer dan penggiat media sosial baik personal maupun komunitas dengan media placement maupun kerjasama non-profit untuk bersama menyebarluaskan informasi ter-update. ITDCdan berbagai pihak yang terait dengan mandalika juga bekerjasama dengan para youtuber untuk merilis update pembangunan sirkuit Mandalika. Relasi dengan berbagai influencer dan youtuber dinilai efektif berdasarkan jumlah tayangan dan terpaan media yang dihasilkan.

\section{Simpulan}

Mandalika sebagai destinasi superprioritas melalui ITDC dan Kementerian terkait menjalankan relasi media untuk menyebarluaskan informasi kesiapan pelaksanaan even MotoGP 2021. Relasi yang dijalankan dengan melakukan konferensi pers, mengeluarkan rilis media dan meningkatkan frekuensi pemberitaan diberbagai media ternama. Strategi media dilakukan dengan memilih media yang kredibel, memiliki exposure tinggi dengan menjadikan key opinion leader sebagai sumber berita. Pemanfaatan media dengan menggunakan 
pendekatan agenda-setting terhadap isu penting melalui pemberitaan digunakan sebagai upaya untuk merubah persepsi publik dari sikap pesismistis ke optimistis dan mendapatkan dukungan untuk pelaksanaan even MotoGP 2021. Relasi media dijalankan ke semua jenis media baik lokal, nasional aupun internasional dengan mempertimbangkan bauran media yang meliputi media internal, media berbayar, media sosial dan endorsement.

\section{Ucapan Terimakasih}

Peneliti mengucapkan terimakasih kepada berbagai pihak yang telah memberikan data serta kesempatan berdiskusi terkait tema penelitian. Terimakasih kepada Management ITDC The Mandalika, Kementerian Pariwisata, Pemerintah Provinsi NTB, Dinas Pariwisata Provinsi NTB, BPPD NTB, Komunitas Pariwisata di NTB serta rekan-rekan media dan pengamat pariwisata atas dukungan dan bantuannya.

\section{Daftar Pustaka}

Abidin, Y.Z. (2015). Manajemen Komunikasi: Filosofi, Konsep, dan Aplikasi. Bandung: Pustaka Setia.

Arifin Anwar (1994). Strategi Komunikasi Sebuah Pengantar Ringkas. Bandung Armico

Biro Komunikasi Kemenkomarves. ( 2020, January 29). Sambut MotoGP 2021 Pemerintah Dukung Penyelesaian Sirkuit Mandalika. Akses dari https://maritim.go.id/sambut-motogp-2021-pemerintah-dukungpenyelesaian-sirkuit-mandalika/

Bungin, Burhan. (2015). Komunikasi Pariwisata Tourism Communication Pemasaran dan Brand Destinasi, Jakarta Prenadamedia Group

Effendy, O,U(2011). Ilmu Komunikasi: Teori dan Prakteknya. Bandung: Remaja Rosdakarya

Griffin E (2010). Communication Theory. New Yok Mc Graw Hill.

Hermalia, (2018) Strategi Komunikasi Pemasaran Kawasan Ekonomi Khusus (KEK) mandalika sebagai destinasi pariwisata prioritas pasca gempa Lombok2018. Journal of Communication and Media Science, Vol.1 No.3, 158- 167

Jefkins, Frank ( 2000). Publik Relation. Jakarta: Erlangga

Kotler, P and Keller, K. L. (2012). Marketing Management. New York: Prentice Hall.

Liputan 6 ( 2019 Maret , 13). Presiden Jokowi Indonesia Siap Gelar MotoGP 2021 di Sirkuit Mandalika. Diakses dari https://www.liputan6.com/bola/read/3915676/presiden-jokowi-indonesia-siap-gelar-motogp-2021-disirkuit-mandalika

Mahrik, A. (2016). Strategi Komunikasi Dinas Komunikasi Informatika Kebudayaan dan Kepariwisataan dalam Meningkatkan Kunjungan Wisatawan di Kabupaten Sinjai. [Skripsi S1, Unpublished]. Jurusan IImu Komunikasi, Fakultas IImu Sosial dan Politik, Universitas Hasanuddin. Sulawesi

Moeleong, Lexy. (2002). Metode Penelitian Kualitatif. Bandung. Remaja Rosdakarya

Prasatya Randy (2020-. November 05). ITDC Ke Kemenpora Tenang Saja Mandalika Slap Gelar MotoGP 2021. Detik.com diakses dari https://sport.detik.com/moto-gp/d-4773454/itdc-ke-menpora-tenang-sajamandalika-siap-gelar-motogp-2021

Priyantono Dony (2020, November 08). Sirkuit Mandalika Siap Gelar MotoGP Meski Tanpa Penonton. Diakses dari Kompas.com https://otomotif.kompas.com/read/2020/11/08/191138215/sirkuit-mandalika-siap-gelarmotogp-meski-tanpa-penonton

Priyantono Dony (2020, November 8). Status GP Mandalika Bukan Cadangan ini Maksudnya Reserve Date. Diakses dari https://otomotif.kompas.com/read/2020/11/08/080100615/status-gp-mandalika-bukancadangan-ini-maksudnya-reserve-date

Rhenald Kasali. (2000) . Managemen Public Relation. Jakarta: Erlangga

Rusy, Putra (2020 Oktober 30). Tinjau Sirkuit Mandalika Dorna Puas. Detik.com diakses dari https://sport.detik.com/moto-gp/d-4764944/tinjau-pembangunan-sirkuit-mandalika-dorna-puas

Wirati Lanjar (2020 Agustus 6). Siap Gelar MotoGP Sirkuit Mandalika Selesai Pertengahan 2021. Diakses dari https://www.indosport.com/otomotif/20200806/siap-gelar-motogp-sirkuit-mandalika-selesaipertengahan-2021 
Rahmadi, Taufan . (2020, 18 Octobers). Personal Interview.

Faozal , Muhammad. ( 2020, 10 November ). Personal Interview

Zakaria, Zakaria. (2020, 20 November). Personal Interview 